$11-16-2015$

Ependymal tumors with oligodendroglioma like clear cells: Experience from a tertiary care hospital in Pakistan

Fauzan Alam Hashmi

Muhammad Faheem Khan

Saad Akhtar Khan

Muhammad Waqas

Muhammad Ehsan Bari

See next page for additional authors

Follow this and additional works at: https://ecommons.aku.edu/pakistan_fhs_mc_surg_neurosurg

Part of the Neurology Commons, Neurosurgery Commons, Pathology Commons, and the Surgery Commons 


\section{Authors}

Fauzan Alam Hashmi, Muhammad Faheem Khan, Saad Akhtar Khan, Muhammad Waqas, Muhammad Ehsan Bari, and Arsalan Ahmed 


\title{
Ependymal tumors with oligodendroglioma like clear cells: Experience from a tertiary care hospital in Pakistan
}

\author{
Fauzan Alam Hashmi, Muhammad Faheem Khan, Saad Akhtar Khan, Muhammad Waqas, \\ Muhammad Ehsan Bari, Arsalan Ahmed ${ }^{1}$ \\ Department of Surgery, Section of Neurosurgery, Aga Khan University, ${ }^{1}$ Department of Pathology, Section of Histopathology, Aga Khan University, Karachi, Pakistan \\ E-mail: *Fauzan Alam Hashmi - fauzan.alam@aku.edu; Muhammad Faheem Khan -dr.mfaheemkhan@gmail.com; Saad Akhtar Khan - saad.akhtar@aku.edu; \\ MuhammadWaqas - muhammad.waqas@aku.edu; Muhammad Ehsan Bari - ehsan.bari@aku.edu; Arsalan Ahmed - arsalan.ahmed@aku.edu \\ *Corresponding author
}

Received: 16 August $15 \quad$ Accepted: 17 September $15 \quad$ Published: 16 November 15

\begin{abstract}
Background: Ependymal tumors with oligodendroglioma like clear cells have never been reported from Pakistan. We aimed to see the features and outcomes of this rare entity.

Methods: It was retrospective cohort conducted at the Department of Neurosurgery, Aga Khan University from 2003 to 2013. The medical records and radiology of patients with proven histopathology were reviewed. Analysis was done on SPSS 20.

Results: Eleven cases of ependymal tumors with clear cells were found, which equated to $1.5 \%$ of the total tumor burden in 11 years. The median age was 49 years. Most common presenting symptom was headache $54.5 \%$. Out of 11 patients, 9 patients had a supratentorial tumor. Magnetic resonance imaging showed hypointense signals on T1 and hyperintense signals on T2-weighted images in all cases. Contrast enhancement was found in 9 patients $(77.8 \%)$, necrosis and hemorrhage was found in $4(36 \%)$ and $3(27 \%)$ patients, respectively. Immunohistochemistry showed glial fibrillary acidic protein and epithelial membrane antigen positivity in all cases. Ki-67 showed high proliferative index in 6 patients. According to the World Health Organization grading of ependymal tumors, 2 patients had Grade II tumors, and 9 patients had Grade III tumors with clear cells. Gross total resection was achieved in $6(54.5 \%)$ and subtotal resection in 5 patients $(45.4 \%)$. Recurrence was observed in 9 patients. Six patients died of the disease. Median progression-free survival and overall survival was 8 months and 10 months, respectively.
\end{abstract}

Conclusion: Ependymal tumors with clear cells presented more commonly in Grade III lesions and were more aggressive in behavior with poorer outcome compared to similar studies.

Key Words: Anaplasia, clear cells, overall survival, progression-free survival, supratentorial

\begin{tabular}{l}
\hline Access this article online \\
\hline Website: \\
www.surgicalneurologyint.com \\
DOI: \\
10.4103/2152-7806.169545 \\
\hline Quick Response Code:
\end{tabular}

\section{INTRODUCTION}

Ependymal tumors are rare neuroepithilial tumor which represent only 2-8\% of all central nervous system (CNS) malignancies. ${ }^{[7]}$ The World Health Organization (WHO) has classified ependymal tumors into: Subependymoma, myxopapillary ependymoma (WHO Grade I), ependymoma (WHO Grade II), and anaplastic ependymoma (WHO Grade III). Ependymoma (WHO Grade II) is further
This is an open access article distributed under the terms of the Creative Commons Attribution-NonCommercial-ShareAlike 3.0 License, which allows others to remix, tweak, and build upon the work non-commercially, as long as the author is credited and the new creations are licensed under the identical terms.

For reprints contact: reprints@medknow.com

How to cite this article: Hashmi FA, Khan MF, Khan SA, Waqas M, Bari ME, Ahmed A. Ependymal tumors with oligodendroglioma like clear cells: Experience from a tertiary care hospital in Pakistan. Surg Neurol Int 2015;6:S583-9.

http://surgicalneurologyint.com/Ependymal-tumors-with-oligodendroglioma-likeclear-cells:-Experience-from-a-tertiary-care-hospital-in-Pakistan/ 
subcategorized into cellular, clear cell, papillary, and tanycytic ependymoma. ${ }^{[10,20,26]}$ Clear cell ependymoma (CCE) is a rare, relatively recent, and diagnostically challenging variant of ependymoma, which was included in the WHO classification of tumors in 1993. [19]

The literature has been scarce on this entity since it was first described in 1983. ${ }^{[16]}$ CCE are mostly supratentorial in location. Other sites described in the literature include cervical and thoracic spinal cord, brain surface, medulla oblongata, fourth ventricle, and cerebellum. $[2,3,8,15,17,18,26,31]$ Tumor cells display classic ependymal rosettes and perivascular pseudorosettes with an oligodendroglioma (ODG) like appearance with a clear perinuclear halo and immune reactivity, showing positivity for glial fibrillary acidic protein (GFAP) and epithelial membrane antigen (EMA). ${ }^{[8,10,15,22]}$

Grade II ependymoma undergo malignant transformation to Grade III and have lower rate of cure even with extensive resection, this is why although CCE is a variant of ependymoma Grade II, but most of the series published to date, show presence of clear cells more in histologically proven anaplastic ependymoma Grade III than Grade II. ${ }^{[26]}$ CCEs have a tendency to be aggressive despite therapy. It is important to distinguish this entity from ODG, central neurocytoma, clear cell carcinoma, and hemangioblastoma mainly because the treatment and prognosis of each differ significantly. ${ }^{[10,12]}$ It is also worth mentioning about some extremely rare entities of ependymal tumors including giant cell ependymoma, ependymoma with lipomatous differentiation, signet ring cell ependymoma, and melanotic ependymoma as they have also been described in the literature. ${ }^{[1,4,9,10,12]}$

To the best of author's knowledge, there is no report on the behavior and outcome of disease from this country and hence we aimed to describe the frequency, clinical, radiological, surgical and histopathological aspects, and outcome of all ependymal tumors containing ODG like clear cells including WHO Grade II and Grade III tumors, managed at our institution along with a review of available literature.

\section{MATERIALS AND METHODS}

This is a retrospective case series of all ependymal tumors containing ODG like clear cells, surgically treated at the section of neurosurgery, Department of Surgery, Aga Khan University, Karachi, Pakistan from January 2003 to December 2013. Medical records of all primary brain neoplasms treated during this period were retrieved from the electronic database of the hospital using ICD code 190.0-191.9.

Data were systematically collected on a structured proforma, which included patient demographics, presenting complaints, duration of symptoms in months, Karnofsky performance score (KPS), radiology, course of treatment including surgery, adjuvant therapy (chemotherapy [CMT] and radiotherapy $[\mathrm{RXT}]$ ), progression-free survival (PFS), and recurrence as suggested by interval 3 monthly magnetic resonance imaging (MRI) of brain and overall survival (OS).

Information about aforementioned aspects were obtained from patient initial out patient Department (OPD) notes, initial assessment forms, progress notes, operative notes retrieved through medical record office, and telephonic calls to patients/attendants were applicable. MRI and computerized tomography (CT) scans of brain were reviewed on picture archiving and communication system of the hospital (PACS) for the location of the tumor to lobe, initial size, and feature specific to tumors such as contrast enhancement, appearance on Tl-weighted and T2-weighted images, and associated characteristics such as presence of mass effect, cystic, hemorrhagic, or necrotic areas were obtained. The histopathology slides were retrieved and reviewed and all the cases that contained the features of ependymal tumors with ODG like clear cells were described by a consultant histopathologist for features including the WHO grade and immunohistochemical stains for the purpose of current study.

Gross total resection (GTR) was defined as excision of more than $95 \%$ of tumor and subtotal resection (STR) was defined as excision of $<95 \%$ tumor.

The data were recorded and analyzed using IBM-SPSS statistics 20 (SPSS 20, IBM, Armonk, NY, United States of America). Median was calculated for continuous variables and frequencies and proportions were calculated for categorical variables. Kaplan-Meier curve analysis was done for PFS and OS.

\section{RESULTS}

In an 11 year period from January 1, 2003, to December 31,2013 , there were a total of 727 cases of primary CNS tumors that were treated surgically at the Aga Khan University, of which there were $51(7 \%)$ cases of ependymal tumors. Histopathologically proven clear cells were found in 11 (1.5\%) cases.

The results showing age, gender, presenting symptoms, and duration of symptoms are summarized in Table 1.

Imaging features

A total of 10 patients had MRI done, 1 patient had CT scans done for diagnosis and progression of the disease secondary to a cardiac pacemaker. The MRI features of all the patients in the series are summarized in Table 2 [Figure 1].

\section{Histopathology}

The histopathological assessment showed diffuse sheets of spindle to epithelioid neoplastic cells embedded within a fibrillary background in all cases. The 
Table 1: Age, gender, presenting symptoms, and duration of symptoms of all the patients in the series

\begin{tabular}{|c|c|c|c|c|c|}
\hline Patient & Age (year) & Sex & Presenting symptoms & $\begin{array}{c}\text { KPS at } \\
\text { presentation }\end{array}$ & $\begin{array}{c}\text { Symptoms } \\
\text { duration (weeks) }\end{array}$ \\
\hline 1 & 40 & Male & Dizziness, GTCS, slowed speech & $>70$ & 24 \\
\hline 2 & 38 & Male & Headaches, right sided weakness & $<70$ & 24 \\
\hline 3 & 55 & Male & Headache, decreased appetite, lethargy, confusion & $>70$ & 8 \\
\hline 4 & 24 & Female & Headache, vomiting & $>70$ & 12 \\
\hline 5 & 40 & Female & GTCS, left hemiparesis & $>70$ & 1.6 \\
\hline 6 & 47 & Male & Headache, GTCS, right sided weakness & $<70$ & 18 \\
\hline 7 & 72 & Male & Hemianopia & $>70$ & 4 \\
\hline 8 & 49 & Female & Pins and needles & $>70$ & 12 \\
\hline 9 & 62 & Male & Headache, vertigo, aural fullness, amnesia & $>70$ & 8 \\
\hline 10 & 62 & Female & Seizures, left sided hemiparesis & $<70$ & 1.5 \\
\hline 11 & 65 & Male & Slurred speech, headache & $>70$ & 1 \\
\hline
\end{tabular}

GTCS: Generalized tonic clonic seizures, KPS: Karnofsky performance score

Table 2: MRI characteristics of all the patients in the series

\begin{tabular}{|c|c|c|c|c|c|c|c|c|c|}
\hline \multirow[t]{2}{*}{ Patient } & \multicolumn{9}{|c|}{ Radiological/MRI characteristics } \\
\hline & Location & Initial size $(\mathrm{cm})$ & Cystic & Hemorrhagic & Necrosis & $\mathrm{C}++$ & $\begin{array}{l}\text { Mass } \\
\text { effect }\end{array}$ & $\begin{array}{l}\text { Signal relative } \\
\text { to cortex } \mathrm{T} 1\end{array}$ & $\begin{array}{c}\text { Signal relative } \\
\text { to cortex } \mathrm{T} 2\end{array}$ \\
\hline 1 & Right frontotemporal & $6.7 \times 7.0 \times 6.0$ & No & No & No & No & Yes & Hypointense & Hyperintense \\
\hline 2 & Left parietal & $6.2 \times 6.0 \times 5.2$ & Yes & No & No & Yes & Yes & Hypointense & Hyperintense \\
\hline 3 & Right temporoparietal & $6.5 \times 4.3 \times 5.8$ & Yes & No & Yes & Yes & Yes & Hypointense to isointense & Hyperintense \\
\hline 4 & Right frontotemporal & $7.3 \times 4.1 \times 5.7$ & Yes & No & No & No & Yes & Hypointense to isointense & Hyperintense \\
\hline 5 & Right parietal & $3.3 \times 4.6 \times 3.5$ & No & No & No & No & No & Hypointense & Hyperintense \\
\hline 6 & $\begin{array}{l}\text { Left occipital + } \\
\text { corpus callosum }\end{array}$ & $\begin{array}{l}7.8 \times 3.2 \times 5.2 \\
3.1 \times 1.7 \times 2.3\end{array}$ & Yes & No & Yes & Yes & Yes & Hypointense & Hyperintense \\
\hline 7 & Left occipital & $2.3 \times 2.2 \times 2.7$ & Yes & Yes & Yes & Yes & No & Isointense & Hyperintense \\
\hline 8 & Right temporoparietal & NA & NA & NA & NA & NA & NA & NA & NA \\
\hline 9 & Right parietal & $2.0 \times 2.9 \times 4.4$ & Yes & Yes & Yes & Yes & No & Isointense to hyperintense & Hyperintense \\
\hline 10 & Right parietal & $3.5 \times 3.0 \times 2.8$ & No & Yes & No & Yes & No & Hypointense & Hyperintense \\
\hline 11 & Right temporal & $4.0 \times 6.2 \times 3.0$ & Yes & No & No & Yes & No & Hypointense & Hyperintense \\
\hline
\end{tabular}

$\mathrm{C++}$ : Contrast enhancement, MRI: Magnetic resonance imaging, NA: Not available

perivascular pseudorosettes were frequent in 8 cases and focal in 3. Clear ODG like cells, suggested by having moderate amount of clear to eosinophilic cytoplasm, moderate pleomorphic, round to oval nuclei surrounded by perinuclear halo were found in few areas in 5 cases, whereas more frequently in 6 cases. Increased cellularity, occasionally prominent nucleoli, atypical mitotic figures, necrosis, and microvascular proliferation was seen in 9 out of 11 patients. Minigemistocytes were seen in 2 cases.

Immunohistochemistry showed that the tumor was GFAP and EMA positive in all cases (100\%). Ki-67 showed low proliferative index in 5 patients and high proliferative index in 6 patients. WHO class was Grade II in 2 patients and Grade III in 9 patients [Figure 2].

\section{Treatment}

Each case was discussed in the multidisciplinary tumor board meeting comprising of consultant neurosurgeons, radiologists, histopathologists, radio-oncologists, senior nurses, and medical oncologists. At the time of writing this article we are following the National Comprehensive Cancer Network (NCCN) USA, clinical practice guidelines in oncology for CNS cancers for the treatment of adult intracranial ependymoma. ${ }^{[24]}$

All 11 patients primarily underwent surgery, out of these 7 patients received concomitant external beam fractionated radiotherapy (EBRT) only, 3 patients received concomitant EBRT and CMT/temozolomide (TMZ), and 1 patient received no therapy (patient's wish) after initial diagnosis.

Recurrence was observed in 9 patients, 1 patient had no evidence of disease (NED) until writing this article, and 1 patient refused for further investigation or treatment. Out of 9 patients who had recurrence of disease, 6 patients did not have further treatment. In the remaining 3 patients repeat surgery was performed, of which 2 patients further received re-RXT and CMT (1 patient was given cisplatin plus etoposide 6 cycles, the other patient was given TMZ 


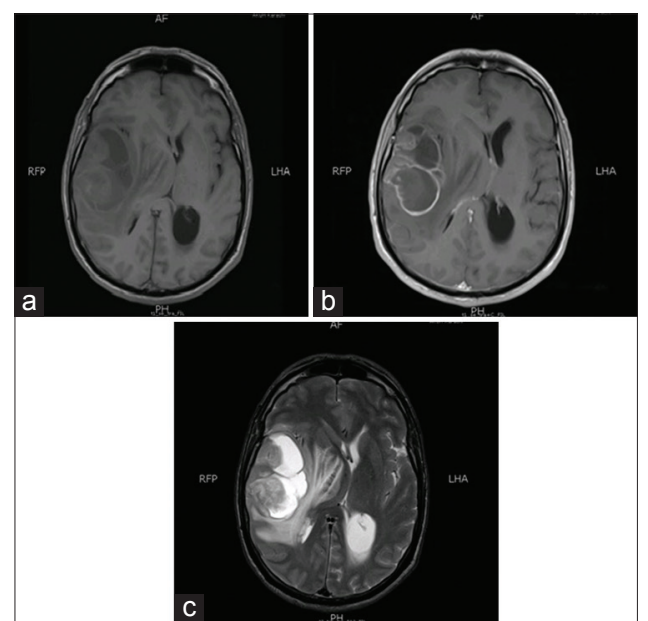

Figure I: Magnetic resonance imaging scans of patient number 3.(a) TI-weighted magnetic resonance image of patient 3 , showing hypo to isointense tumor in right temporoparietal cortex with compression and near effacement of right lateral ventricle, subfalcine herniation, and midline shift. (b) TI with gadolinium of the same patient showing subtle peripheral ring enhancement and loculations.(c) T2-weighted image of the same patient showing cystic areas with solid component displaying hyperintense signals

6 cycles), whereas 1 patient received re-RXT alone.

Six patients expired of the disease. One patient refused for any further treatment post-GTR and expired 5 months after the primary surgery. Four underwent EBRT postprimary surgery, one of them remained progression free for almost 28 months postprimary surgery, underwent repeat surgery twice within an interval of 5 months followed by TMZ and re-RXT, and she expired on 52 months postprimary surgery. Three more underwent EBRT but had progression of disease, 2 patients underwent concomitant CMT (one with TMZ 6 cycles and other with cisplatin and etoposide 6 cycles) along with re-RXT. The patient with TMZ + re-RXT was dead of the disease 10 months postprimary surgery and patient with cisplatin plus etoposide + re-RXT had metastasis to corpus callosum, thalamus and had dural deposits, he was lost to follow-up at 19 months from primary surgery.

Currently, 4 patients are under follow-up until writing this article. One patient underwent STR, followed by concomitant TMZ, and EBRT had reduction in residual size and has no evidence of progression 10 months from the surgery. The second patient underwent GTR followed by EBRT in Italy, he remained progression free for 12 months however, the tumor recurred, he refused further treatment, he is alive on 67 weeks since his primary surgery; however, currently he is bedridden, dependent for all his activities, KPS 20. The third patient STR, her initial histology shows features of ODG, she was followed by TMZ and EBRT; however, her tumor recurred at 8 month postsurgery, she again underwent STR, this time the histopathology showed CCE, she underwent

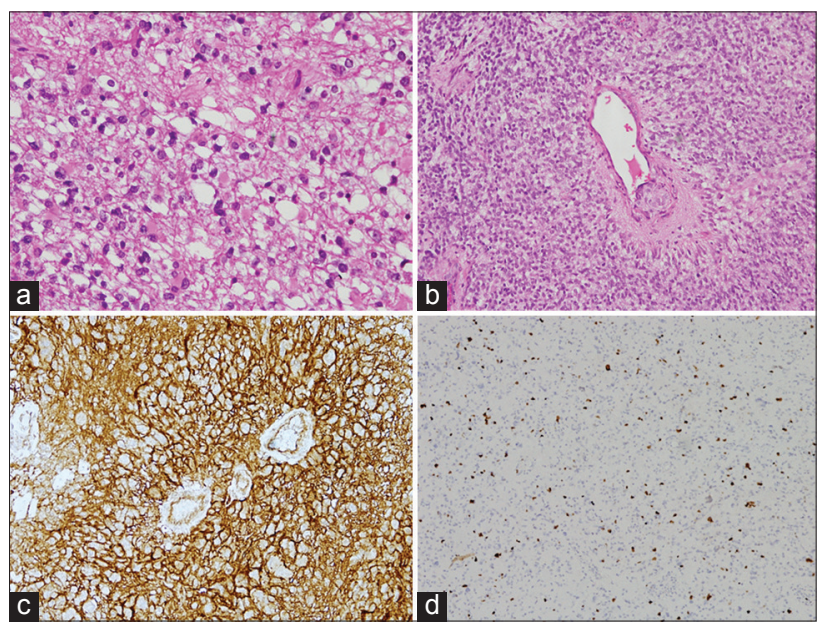

Figure 2: Histopathological slides of the patients in the series. (a) $\mathrm{H}$ and $\mathrm{E}$ stain of patient I, showing clear cell morphology. (b) $\mathrm{H}$ and $\mathrm{E}$ stain of patient $\mathrm{I}$, showing perivascular pseudorosettes. (c) Slide displaying epithelial membrane antigen positivity in patient number 2.(d) Slide showing 10-15\% (high) Ki-67 positivity in patient number 5

re-RXT, currently she has NED for 10 months post re-surgery, total 18 months from first surgery. The fourth patient underwent GTR + EBRT and had recurrence at 3 months and currently has stable disease at 5 months.

The median PFS was 8 months ranging from minimum 3 months and maximum 28 months, and the median OS was 10 months (range 6 months-52 months) after primary surgery. The extent of resection, intraoperative tumor findings, initial diagnosis, treatment given, recurrence, PFS, and OS are summarized in Table 3 [Figure 3].

\section{DISCUSSION}

CCE is considered to be Grade II supratentorial and extraventricular tumor, occurring predominantly in young patients. ${ }^{[3+]}$ The histopathological classification described by WHO has defined CCE as a variant of ependymoma Grade II, however, we have 9 out of 11 cases showing the ependymal clear cells in anaplastic ependymoma Grade III instead of ependymoma Grade II. The literature has also described more cases of ODG like clear cells present in anaplastic ependymoma Grade III rather than ependymoma Grade II. . $^{[6,8,13,22,28,30]}$

Interestingly, the median age of our series was 49 years (age range 24-72 years). This was significantly different from the cohorts of Fouladi et al..$^{[8]}$ Rickert et al. ${ }^{[30]}$ the two biggest cohorts on the subject who have reported this disease in pediatric age group along with others who have also reported this disease in the pediatric age group. ${ }^{[11,27,28]}$ Similar to our age group, we found comparable cohorts of Kawano et al., Min and Scheithauer ${ }^{[16,23]}$ along with few case reports from others. $[3,5,14,31-33]$ 
Table 3: Lists the EOR, gross morphology, initial diagnosis, treatment, and outcome

\begin{tabular}{|c|c|c|c|c|c|c|c|}
\hline Patient & EOR & $\begin{array}{l}\text { Intraoperative gross tumor } \\
\text { morphology }\end{array}$ & $\begin{array}{l}\text { Initial } \\
\text { diagnosis }\end{array}$ & Recurrence & $\begin{array}{c}\text { PFS } \\
\text { (months) }\end{array}$ & Overall therapy & $\begin{array}{l}\text { Overall survival/ } \\
\text { outcome (months) }\end{array}$ \\
\hline 1 & GTR & Soft, vascular, adherent to vessels & CCE & Local & 12 & GTR + EBRT 60 Gy 30 fractions & SD at 16 months \\
\hline 2 & GTR & Hard, vascular, sclerotic & ODG & $\begin{array}{l}\text { Spread to } \\
\text { corpus callosum, } \\
\text { thalamus, dural } \\
\text { deposits }\end{array}$ & 4 & $\begin{array}{l}\text { Surgery + EBRT } 54 \text { Gy in } 30 \\
\text { fractions outside our hospital } \\
\text { GTR in our hospital + cisplatin } \\
+ \text { etoposide } 6 \text { cycles + } \\
\text { re-radiotherapy }\end{array}$ & $\begin{array}{l}\text { Lost to follow-up } \\
4 \text { months after } \\
\text { second surgery }\end{array}$ \\
\hline 3 & GTR & Soft, yellowish, moderately vascular & CCE & & & No therapy & DOD at 6 months \\
\hline 4 & STR & $\begin{array}{l}\text { Solid cum cystic, yellowish, } \\
\text { moderately vascular }\end{array}$ & CCE & None & 10 & $\begin{array}{l}\text { STR + TMZ + EBRT } 60 \mathrm{~Gy} \\
30 \text { fractions }\end{array}$ & NED at 10 months \\
\hline 5 & $\begin{array}{l}\text { STR } \\
\text { STR }\end{array}$ & $\begin{array}{l}\text { Soft, mildly vascular (surgery } 1 \text { ) } \\
\text { Soft, mildly vascular, easily separable } \\
\text { (surgery } 2 \text { ) }\end{array}$ & ODG & Local & 8 & $\begin{array}{l}\text { STR + TMZ + EBRT } 60 \text { Gy } \\
30 \text { fractions } \\
\text { STR + re-radiotherapy }\end{array}$ & $\begin{array}{l}\text { SD at } 18 \text { months } \\
\text { post first } \\
\text { symptoms }\end{array}$ \\
\hline 6 & STR & Grayish white, moderately vascular & CCE & Local & 5 & $\begin{array}{l}\text { STR }+ \text { TMZ + EBRT } 60 \text { Gy } \\
30 \text { fractions }\end{array}$ & DOD at 10 months \\
\hline 7 & GTR & Soft, grayish white, moderately vascular & CCE & Local & 6 & GTR + EBRT 60 Gy 30 fractions & DOD 10 months \\
\hline 8 & $\begin{array}{l}\text { STR } \\
\text { STR } \\
\text { STR }\end{array}$ & $\begin{array}{l}\text { Soft, grayish yellow, moderately } \\
\text { vascular, cystic (surgery 1) } \\
\text { Vascular, cyst (surgery } 2 \text { and } 3 \text { ) }\end{array}$ & ODG & Local & 28 & $\begin{array}{l}\text { STR + EBRT } 54 \text { Gy } 30 \text { fractions } \\
\text { STR + CMT (undocumented) + } \\
\text { re-radiotherapy } \\
\text { STR }\end{array}$ & DOD at 52 months \\
\hline 9 & GTR & $\begin{array}{l}\text { Soft, moderately vascular with } \\
\text { thrombosed vessels, adherent to dura }\end{array}$ & CCE & Local & 5 & GTR + EBRT 54 Gy 30 fractions & $\mathrm{DOD}$ at 10 months \\
\hline 10 & GTR & Soft, vascular with thrombosed vessels & CCE & Local & 3 & GTR + EBRT 60 Gy 30 fractions & SD at 5 months \\
\hline 11 & STR & Soft, yellowish, moderately vascular & CCE & $\begin{array}{l}\text { Frontal, } \\
\text { periventricular, } \\
\text { posterior fossa }\end{array}$ & 8 & STR + EBRT 54 Gy 30 fractions & DOD at 9 months \\
\hline
\end{tabular}

CCE - Ependymal tumor with ODG like clear cells. GTR: Gross total resection, STR: Subtotal resection, ODG: Oligodendroglioma, EBRT: External beam fractionated radiotherapy, TMZ:Temozolomide, CMT: Chemotherapy, DOD: Dead of disease, NED: No evidence of disease, SD: Stable disease, KPS: Karnofsky performance scale, EOR: Extent of resection, CCE: Clear cell ependymoma

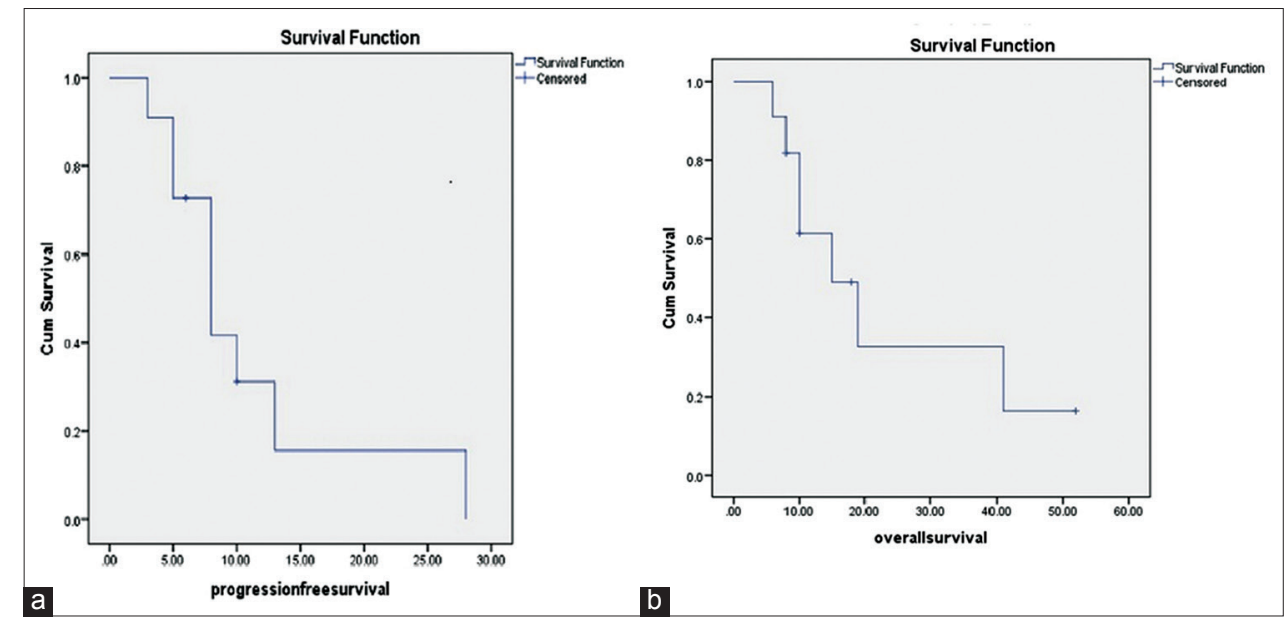

Figure 3: Kaplan-Meir curves for progression-free survival and overall survival.(a) Kaplan-Meir curve showing progression-free survival in months in the series.(b) Kaplan-Meir curve showing overall survival in months in the series

The treatment of intracranial ependymoma as suggested by NCCN guidelines 2014[24,25] include GTR if feasible, followed by MRI spine for drop mets if histopathology is suggestive of anaplastic ependymoma Grade III, followed by limited EBRT 54-59.4 Gy, in 1.8-2.0 Gy fractions. In case of recurrence, re-resection is recommended if resectable followed by EBRT if no prior RXT is received and in case if prior RXT is given, then consider re-irradiation or CMT with platinum-based, etoposide, nitrosourea, bevacizumab, or palliation. The regimen of ODG necessitates the use of adjuvant TMZ with EBRT, 45-54 Gy in case of low-grade gliomas (Grade I and II), 
and recommended 60 Gy in case of high-grade gliomas (Grade III and IV).

The clinical presentation is similar to that reported in other studies. ${ }^{\left[{ }^{[8]}\right.}$ The primary tumor site was supratentorial in 9 out of 10 patients of Fouladi et al. and all cases in Min and Scheithauer ${ }^{[23]}$ case series. Rickert et al. ${ }^{[30]}$ case series of $13 \mathrm{CCE}$ also concluded similar location with 12 CCE in supratentorial and 1 in infratentorial compartment. Most case series have described the tumor in supratentorial compartment. ${ }^{[22,31]}$ However, Kawano's second series showed all 6 cases in cerebellum, whereas his first series showed 2 of 4 cases in cerebellum. Furthermore, occipital CCE has also been reported in the literature ${ }^{[16,17,27,28]}$ and to add on Amatya et al. ${ }^{[3]}$ reported CCE in medulla oblongata, Katoh et al. ${ }^{[15]}$ reported a case in the fourth ventricle. None of our patients had the tumor in cerebellum, fourth ventricle, or medulla oblongata. Kurt et al. suggested that there is no significant difference in OS of supratentorial CCE and infratentorial CCE. ${ }^{[21]}$

With respect to radiological features, Fouladi et al. ${ }^{[8]}$ described most cases to be isointense on both Tl- and T2-weighted images. Enhancement was present in all cases, and most had associated cysts with enhancing walls. Fifty percentage of the tumors had associated hemorrhage, $70 \%$ tumors had regions of necrosis, and most had mass effect. Hayashi et al. described the tumor as having calcification on CT scan brain and cystic cum solid hypo- to iso-intense contrast enhancing tumor on $\mathrm{Tl}$ and hyperintense tumor on T2-weighted images of MRI. ${ }^{[11]}$ Sato et al. also observed hypointense signals on $\mathrm{Tl}$, contrast enhancement, and cystic component. ${ }^{[31]}$

In our study, we observed hypointense signals on $\mathrm{Tl}$ and hyperintense signals on T2-weighted images, associated cysts, and enhancement in 9 out of 11 patients, mass effect was present in 5 patients; however, necrosis and hemorrhage were present in 4 and 3 patients, respectively.

Similar findings were reported by other authors. ${ }^{[3,13,15,22]}$

The gross intraoperative examination of the tumor is rarely reported in the literature, Jain et al. ${ }^{[13]}$ reported one of the cases as soft and vascular and the other case as fleshy and vascular, Amatya et al. ${ }^{[3]}$ described the tumor as having cystic and nodular parts, cystic was well circumscribed purplish red and nodular was hard in consistency, Lee et al. described their finding as yellowish brown, soft, friable tumor, ${ }^{[22]}$ Sato et al. also had yellow-grayish tumor. ${ }^{[31]}$ This is comparable to gross examination of our tumors most of which were also yellowish brown, soft, moderately vascular, and having solid and cystic components.

WHO has not clearly defined the histological criteria to classify the tumor as CCE with respect to the percentage of ODG like clear cells and ependymoma like areas present. Fouladi et al. ${ }^{[8]}$ suggested that features of clear cells varied from focal to diffuse with focal necrosis in all patients, in Rickert et al. series clear cells varied from focal to diffuse. ${ }^{[30]}$ Others also had reported sheets of clear cells, focal perivascular pseudorosettes, whereas true ependymal canals and rosettes were absent. ${ }^{[9,15,19]}$ Kurt et al. declared MIB l (Ki-67) as the most important prognostic factor in defining anaplasia in ependymoma. ${ }^{[21]}$

The median PFS of our study was $8 \pm 6.7$ months postsurgery, and median OS was $10 \pm 14$ months postsurgery. This was significantly different from the cohorts of Kawano et al., ${ }^{[16]}$ Min and Scheithauer, ${ }^{[23]}$ Fouladi et al., ${ }^{[8]}$ and Kawano et al. ${ }^{[16]}$ first 2 cases were dead of disease in 52 and 20 months, other cases survived for more than 100 months. Rickert et al. ${ }^{[30]}$ survival (mean $>52$ months) was also better than our cohort. Fouladi et al. ${ }^{[8]} 5$ years PFS was $34 \pm 20 \%$ and OS $75 \pm 19 \%$. None of our patients survived up to 5 years. Maximum PFS was 28 months in 1 patient, and maximum OS was 52 months in the same patient. To our comparison is a series of 3 cases by Jain $\mathrm{D},{ }^{[13]}$ from India, 1 patient lost to follow-up at 4 months, 1 died of disease at 21 , and other at 24 months. This may suggest that in this part of the world India and Pakistan, this tumor is comparatively more aggressive than in Japan, the United States of America, and Australia.

Our cohort highlights the significant amount of misdiagnosis and confusion in diagnosing CCE; this highlights the use of more precise immunohistochemical stains and cytogenetic testing to confirm the diagnosis. Preusser et al. described OLIG-2 an additional immunohistochemical marker to differentiate between ODG and CCE. ${ }^{[29]}$ Fouladi et al. showed deletion of CEP18 and DALl and polysomy of $1 \mathrm{p}, 19 \mathrm{q}$, and NF2 loci in CCE ${ }^{[8]}$ Rickert et al. showed genomic aberration at chromosome 9 in ependymoma Grade II, and $+\mathrm{lq}$, $+13 \mathrm{q}$, and $-9,-3,-22$ in anaplastic ependymoma Grade III. ${ }^{[30]}$ Because of financial and resource constraints we were unable to perform these tests and comment on these aspects of the tumor at this moment, however, we aspire to study and comment on cytogenetics in near future.

Our limitation was a small sample size, a single institution data, and a retrospective study design. This is the first report from Pakistan addressing a detailed description of clinical, radiological, and histopathological features of this tumor.

\section{CONCLUSION}

Ependymal tumors mixed with ODG like clear cells constituted only $1.5 \%$ of all the CNS tumors presenting at our institute over past 11 years. A 
correct histopathological diagnosis aided with precise immunohistochemical stains and cytogenetic testing is critical for appropriate management and better outcome. In contrast to previous reports, we found majority of our patients (9 out of 11) had Grade III ependymal tumor with clear cells which may suggest a more aggressive disease on presentation, which may account for a poorer outcome in our cohort. However, our results were concordant with results reported from India, suggesting a possibility of more aggressive disease in this region.

\section{Acknowledgments}

The authors would like to thank Dr. Khabir Ahmed for his assistance in writing the article.

\section{Financial support and sponsorship}

Nil.

\section{Conflicts of interest}

There are no conflicts of interest.

\section{REFERENCES}

I. Adamek D, Dec M, Sobol G, Urbanowicz B, Jaworski M. Giant cell ependymoma: A case report. Clin Neurol Neurosurg 2008; I 10:176-8I.

2. Akutsu H, Shibata Y, Okazaki M, Hyodo A, Matsumura A. Intramedullary clear cell ependymoma in the cervical spinal cord: Case report. Neurosurgery 2000;47:1434-7.

3. Amatya VJ, Takeshima Y, Kaneko M, Nakano T, Yamaguchi S, Sugiyama K, et al. Case of clear cell ependymoma of medulla oblongata: Clinicopathological and immunohistochemical study with literature review. Pathol Int 2003;53:297-302.

4. Brown DF, Chason DP, Schwartz LF, Coimbra CP, Rushing EJ. Supratentorial giant cell ependymoma: A case report. Mod Pathol 1998; 11:398-403.

5. Cenacchi G, Giangaspero F, Cerasoli S, Manetto V, Martinelli GN. Ultrastructural characterization of oligodendroglial-like cells in central nervous system tumors. Ultrastruct Pathol 1996;20:537-47.

6. Deb P, Manu V, Pradeep H, Bhatoe HS. Intraparenchymal clear cell ependymoma. J Cytol 20I I;28:73-6.

7. Dützmann S, Schatlo B, Lobrinus A, Murek M, Wostrack M, Weiss C, et al. A multi-center retrospective analysis of treatment effects and quality of life in adult patients with cranial ependymomas. J Neurooncol 20 13; | 14:3 | 9-27.

8. Fouladi M, Helton K, Dalton J, Gilger E, Gajjar A, Merchant T, et al. Clear cell ependymoma: A clinicopathologic and radiographic analysis of 10 patients. Cancer 2003;98:2232-44.

9. Fourney DR, Siadati A, Bruner JM, Gokaslan ZL, Rhines LD. Giant cell ependymoma of the spinal cord. Case report and review of the literature.J Neurosurg 2004; 100:75-9.

10. Fuller GN, Scheithauer BW. The 2007 revised World Health Organization (WHO) classification of tumours of the central nervous system: Newly codified entities. Brain Pathol 2007; 17:304-7.

II. Hayashi K, Tamura M, Shimozuru T, Kasamo S, Hirahara K, Kadota K, et al. Extra-axial ependymoma-Case report.Neurol Med Chir (Tokyo) 1994;34:295-9.

12. Ho DM, Hsu CY, Wong TT, Chiang H. A clinicopathologic study of 81 patients with ependymomas and proposal of diagnostic criteria for anaplastic
ependymoma.J Neurooncol 200 I;54:77-85.

13. Jain D, Sharma MC, Arora R, Sarkar C, Suri V. Clear cell ependymoma: A mimicker of oligodendroglioma - Report of three cases. Neuropathology 2008;28:366-71.

14. Kakita A, Takahashi H, Fusejima T, Konno K, Nakazawa T, Aoki K, et al. Clear cell variants of intracranial tumors: Meningioma and ependymoma. Noshuyo Byori 1995; 12:1 II-6.

15. Katoh M, Satoh T, Nishiya M, Murata J, Ishii N, Saitoh H, et al. Clear cell ependymoma of the fourth ventricle. Neuropathology 2004;24:330-5.

16. Kawano N, Yada K, Aihara M, Yagishita S. Oligodendroglioma-like cells (clear cells) in ependymoma. Acta Neuropathol 1983;62:141-4.

17. Kawano N,Yada K, Yagishita S. Clear cell ependymoma.A histological variant with diagnostic implications. Virchows Arch A Pathol Anat Histopathol 1989;415:467-72.

18. Kim YJ, Tsunoda S, Yokoyama K, Miyamoto K, Tamai M, Yamauchi M. Clear cell ependymoma with a lipidized component that developed in the thoracic spinal cord. Neurol Res 2003;25:324-8.

19. Kleihues P, Burger PC, Scheithauer BW.The new WHO classification of brain tumours. Brain Pathol 1993;3:255-68.

20. Kleihues P, CaveneeWK. Pathology and Genetics of Tumours of the Nervous System. Lyon, France: International Agency for Research on Cancer; 2000.

21. Kurt E, Zheng PP, Hop WC, van derWeiden M, Bol M, van den Bent MJ, et al. Identification of relevant prognostic histopathologic features in 69 intracranial ependymomas, excluding myxopapillary ependymomas and subependymomas. Cancer 2006; 106:388-95.

22. Lee BH, Kwon JT, Park YS. Supratentorial clear cell ependymoma mimicking oligodendroglioma: Case report and review of the literature. J Korean Neurosurg Soc 201 I;50:240-3.

23. Min KW, Scheithauer BW. Clear cell ependymoma: A mimic of oligodendroglioma: Clinicopathologic and ultrastructural considerations. Am J Surg Pathol 1997;21:820-6.

24. Nabors LB, Ammirati M, Bierman PJ, Brem H, Butowski N, Chamberlain MC, et al. Central nervous system cancers. J Natl Compr Canc Netw 2013; I I: I | 4-5I.

25. Network NCC. NCCN Clinical Practice Guidelines in Oncology: Central Nervous System Cancers. Ver. 2. 20I4. Fort Washington, PA, USA: Network NCC; 2014

26. Packer RR, Schiff D. Neuro-oncology. Hoboken, NJ, USA: John Wiley and Sons; 2012.

27. Parafeynikov V, Boaz JC, Bonnin JM. Clear-cell ependymoma: A report of intracortical tumor with significant desmoplasia. Neuropathology 2008;28:165-70.

28. Payet M, Conter C, Labrousse F, De Paula AM, Marabelle A, Branger DF, et al. Clear cell ependymoma with trisomy 19 developing bone metastases. Childs Nerv Syst 2012;28:739-42.

29. Preusser M, Budka H, Rössler K, Hainfellner JA. OLIG2 is a useful immunohistochemical marker in differential diagnosis of clear cell primary CNS neoplasms. Histopathology 2007;50:365-70.

30. Rickert $\mathrm{CH}, \mathrm{Korshunov} \mathrm{A}$, Paulus W. Chromosomal imbalances in clear cell ependymomas. Mod Pathol 2006;19:958-62.

3I. Sato Y, Ochiai H, Yamakawa Y, Nabeshima K, Asada Y, Hayashi T. Brain surface ependymoma. Neuropathology 2000;20:315-8.

32. Seyithanoglu H, Guzey FK, Emel E, Alatas I, Acarbas A, Ozkan N. Clear cell ependymoma of the temporal lobe in a child: A case report. Pediatr Neurosurg 2008;44:79-84.

33. Suh JH, Hong SM, Lee IC. Clear cell ependymoma. Korean J Pathol 1997;31:383-7.

34. Teo C, Nakaji P, Symons P, Tobias V, Cohn R, Smee R. Ependymoma. Childs Nerv Syst 2003;19:270-85. 